Asian Pacific Journal of Reproduction

Journal homepage: www.apjr.net

\title{
Effects of L-Arginine supplementation on semen quality, testosterone concentration and testes histological parameters of Ross 308 breeder roosters
}

\author{
Ahangar $\mathrm{M}^{1}$, Asadzadeh $\mathrm{S}^{1}$, Rezaeipour $\mathrm{V}^{1 凶}$, Zareh Shahneh $\mathrm{A}^{2}$ \\ ${ }^{\prime}$ Department of Animal Science, Qaemshahr Branch, Islamic Azad University, Qaemshahr, Iran \\ ${ }^{2}$ Department of Animal Science, Faculty of Agricultural and Natural Resources, University of Tehran, Tehran, Iran
}

\section{ARTICLE INFO}

Article history:

Received 12 March 2017

Revision 2 April 2017

Accepted 15 April 2017

Available online 1 May 2017

Keywords:

Rooster

Arginine

Reproductive performance

Semen quality

\begin{abstract}
Objective: To assess the effects of dietary L-Arginine (L-Arg) supplementation on testes histological parameters and semen quality of male broiler breeder. Methods: Twenty male broiler breeders at $37 \mathrm{wk}$ of age were distributed in a completely randomized design with 4 treatments and 5 replicates each. The treatments consisted of 4 dietary levels of L-Arg $(0.00$, $1.35,2.33$ and $3.22 \mathrm{~g} / \mathrm{kg}$ of the diet) and fed to birds for $8 \mathrm{wk}$. At the end of the experiment semen samples were collected by abdominal massage to determination of semen quality. The blood samples were used to determination of serum testosterone concentration at the end of the experiment. Furthermore, testes from each rooster were used to evaluation of their weights and histological parameters. Results: The results of the experiment showed that dietary L-Arg at $2.33 \mathrm{~g} / \mathrm{kg}$ improved testes weight, semen volume and sperm forward motility in roosters $(P<0.05)$. Besides, serum concentration of testosterone was increased in roosters fed $2.33 \mathrm{~g} / \mathrm{kg} \mathrm{L}-\mathrm{Arg}$ $(P<0.05)$. The results of testes histology indicated that seminiferous tubules lumen diameter, leydig cells, spermatides and sperm cells counts were greater in birds received $3.22 \mathrm{~g} / \mathrm{kg}$ dietary L-Arg $(P<0.05)$. However, the birds fed diet supplemented with $2.33 \mathrm{~g} / \mathrm{kg} \mathrm{L}-\mathrm{Arg}$ had greater seminiferous tubules diameter, sertoli and spermatogonia cell counts than other groups $(P<0.05)$. Conclusion: According to the results of this experiment, it is concluded that dietary $\mathrm{L}-\mathrm{Arg}$ had positive effects on reproductive traits in roosters.
\end{abstract}

\section{Introduction}

Producing the maximum number of fertile eggs is one of the most important concerns in broiler breeder production. Breeders need to be kept under ideal conditions for maximum life of flock fertility. Several authors reported that environmental condition such as nutritional program has an important role on semen quality and reproductive performance of male broiler and layer breeders[1-4].

The influence of Arginine in treating many developmental and health problems in animals is unique among essential amino acids. It is well demonstrated that the metabolism of L-Arginine occurs through the interorgan axis, which involves kidney, intestines, muscle, liver and testis[5]. The results of an in vitro experiment showed that boar sperm capacitating and acrosome reaction are

Corresponding author: Vahid Rezaeipour, Department of Animal Science, Qaemshahr Branch, Islamic Azad University, Qaemshahr, Iran.

E-mail: vrezaeipour@gmail.com improved by L-Arginine supplementation[6]. It is reported that L-Arginine is the only physiological nitrogen donor the reactions of nitric oxide production[7]. Nitric oxide, also known as nitrogen monoxide, produces from L-Arginine by the enzymatic action of nitric oxide synthase. The nitric oxide synthase is a key enzyme controlling nitric oxide production and sperm characteristics' is improved when nitric oxide concentration increases[8]. In the last decade, nitric oxide which is a highly reactive free radical has assumed an important functional role in a variety of biological

This is an open access article distributed under the terms of the Creative Commons Attribution-Non Commercial-Share Alike 3.0 License, which allows others to remix, tweak and buid upon the work non-commercially, as long as the author is credited and the new creations are licensed under the identical terms.

For reprints contact: reprints@ medknow.com

(C)2017 Asian Pacific Journal of Reproduction Produced by Wolters Kluwer- Medknow

How to cite this article: Ahangar M, Asadzadeh S, Rezaeipour V, Zareh Shahneh A. Effects of L-Arginine supplementation on semen quality, testosterone concentration and testes histological parameters of Ross 308 breeder roosters. Asian Pac J Reprod 2017; 6(3): 133-135. 
pathways such as a decisive role in the reproductive system[9]. It was hypothesized that L-Arginine supplementation to breeder rooster may improve reproductive performance and semen quality via the nitric oxide pathway.

Therefore, the aim of this research was to investigate whether diatary L-Arginine influences reproductive performance, semen quality and testes weight of male broiler breeder.

\section{Materials and methods}

All animal care and use procedures were approved by the Department of Animal Science, Islamic Azad University (Qaemshar Branch, Qaemshar, Iran).

\subsection{Birds and diets}

Thirty two 37-wk-old breeder roosters (Ross 308) were obtained from a commercial broiler breeder farm and randomly allocated into 4 treatments with 5 replicates. The birds were kept in floor pens (1 $\times 2 \mathrm{~m}$ ) for the experimental period of $56 \mathrm{~d}$. Each pen was equipped with a separate feeder and drinker. The roosters were maintained under similar conditions at $21^{\circ} \mathrm{C}$. All experimental diets were formulated to meet or exceed the energy and nutrient requirements (except for arginine) of roosters[10]. The experiment used a completely randomized design with 4 treatments including 4 dietary L-Arg inclusion rates of $0.00,1.35,2.33$ and $3.22 \mathrm{~g} / \mathrm{kg}$.

\subsection{Semen collection and evaluation}

The roosters were habituated (for $10 \mathrm{~d}$ ) by abdominal massage for semen collection. The seminal fluid from each rooster was collected every week and seminal characteristics were evaluated. The semen from each rooster was kept in a graduated collecting tube to measuring of seminal volume. A part of the semen was diluted (1:100) by a $2.9 \%$ sodium citrate solution. Then, each sample was placed on a slide and the motility was evaluated by a light microscope. Motility was expressed as a percentage of spermatozoa progressively exhibiting moderate to rapid movement[1].

\subsection{Testosterone concentration}

Heparinized blood samples $(5 \mathrm{~mL})$ were taken from each rooster via the brachial wing vein at the end of the experiment. The blood sample was drawn and allowed to clot at room temperature (18 ${ }^{\circ} \mathrm{C}$ ) for $2 \mathrm{~h}$ prior to serum collection. Serum was separated by centrifugation and stored at $-20{ }^{\circ} \mathrm{C}$ for further analysis. Serum testosterone was also assayed by ELISA procedure.

\subsection{Testes histology}

At the end of the study, 4 rosters from each treatment were killed and testes were excised for histological assessment. The left testis of each rooster was cut into serial cross-sections $5 \mathrm{~mm}$ in thickness, fixed in $10 \%$ neutral buffered formalin, embedded in paraffin, sectioned, and stained with hematoxylin and eosin for routine histological examination. Histological examination of 2 preparations of the left testis of each bird was conducted blindly under light microscope.

\subsection{Statistical analysis}

Statistical analysis was conducted using general linear model procedure of SAS to evaluate the effects of treatments on reproductive traits[11]. The result with $P<0.05$ was considered statistically significant

\section{Results}

The results of semen quality and testosterone concentration are presented in Table 1. According to the results, semen volume and sperm forward motility improved in male broiler breeders received $2.33 \mathrm{~g} / \mathrm{kg}$ dietary L-Arg supplementation $(P<0.05)$. The results of this table also indicated that the testes weight was greater in roosters fed $2.33 \mathrm{~g} / \mathrm{kg}$ dietary L-Arg $(P<0.05)$. Dietary L-Arg had a positive effect on the serum concentration of testosterone in male broiler breeders $(P<0.05)$. In this regard, the birds fed diets with $2.33 \mathrm{~g} / \mathrm{kg}$ L-Arg had greater serum testosterone than the other groups.

Table 1

Effects of L-Arg supplementation on semen quality and testosterone concentration in male broiler breeder.

\begin{tabular}{|c|c|c|c|c|c|}
\hline \multirow{2}{*}{ Traits } & \multicolumn{4}{|c|}{ Dietary L-Arg ( $\mathrm{g} / \mathrm{kg}$ of the diet) } & \multirow{2}{*}{ SEM } \\
\hline & 0.00 & 1.35 & 2.33 & 3.22 & \\
\hline ume (mL/bird) & $0.38^{\mathrm{d}}$ & $0.50^{\mathrm{c}}$ & $0.88^{\mathrm{a}}$ & $0.74^{\mathrm{b}}$ & 0.08 \\
\hline Sperm motility (\%) & $73.87^{\mathrm{d}}$ & $80.27^{\mathrm{c}}$ & $88.00^{\mathrm{a}}$ & $84.21^{\mathrm{b}}$ & 2.43 \\
\hline erone (pg/Ml) & $2.63^{\mathrm{d}}$ & $5.16^{\mathrm{c}}$ & $8.17^{\mathrm{a}}$ & $6.45^{\mathrm{b}}$ & 0.92 \\
\hline Testes weight (g) & $22.70^{\mathrm{d}}$ & $31.45^{\mathrm{c}}$ & $43.90^{\mathrm{a}}$ & $35.25^{\mathrm{b}}$ & 1.14 \\
\hline
\end{tabular}

The effects of dietary L-Arg on the testes histological traits are shown in Table 2. The results showed that Seminiferous tubules lumen diameter, leydig cells and spermatides counts were greater in male broiler breeder received $3.22 \mathrm{~g} / \mathrm{kg}$ dietary L-Arg supplementation $(P<0.05)$. On the other hand, other histological traits including seminiferous tubules diameter, sertoli cell counts and spermatogonia cell counts were increased in group that received 2.33 $\mathrm{g} / \mathrm{kg}$ diatary L-Arg $(P<0.05)$.

Table 2

Effects of L-Arg supplementation on testes histology in male broiler breeder.

\begin{tabular}{|c|c|c|c|c|c|}
\hline \multirow{2}{*}{ Traits } & \multicolumn{4}{|c|}{ Dietary L-Arg (g/kg of the diet) } & \multirow{2}{*}{ SEM } \\
\hline & 0.0000 & 1.3500 & 2.3300 & 3.2200 & \\
\hline $\begin{array}{l}\text { Seminiferous } \\
\text { tubules lumen } \\
\text { diameter }(\mu)\end{array}$ & $0.0047^{\mathrm{d}}$ & $0.0056^{\mathrm{c}}$ & $0.0081^{\mathrm{b}}$ & $0.0086^{\mathrm{a}}$ & 0.0003 \\
\hline Leydig cells & $160.8000^{b}$ & $160.1000^{b}$ & $191.8000^{\mathrm{a}}$ & $194.0000^{\mathrm{a}}$ & 4.1300 \\
\hline $\begin{array}{l}\text { Spermatides } \\
\text { counts }\end{array}$ & $154.5000^{c}$ & $158.6000^{c}$ & $174.0000^{\mathrm{b}}$ & $179.6000^{\mathrm{a}}$ & 3.9100 \\
\hline $\begin{array}{l}\text { Seminiferous } \\
\text { tubules diameter }(\mu)\end{array}$ & $0.0480^{c}$ & $0.0520^{b}$ & $0.0630^{\mathrm{a}}$ & $0.0620^{\mathrm{a}}$ & 0.0020 \\
\hline Sertoli cell counts & $115.2000^{\mathrm{b}}$ & $116.5000^{b}$ & $126.7000^{\mathrm{a}}$ & $125.3000^{\mathrm{a}}$ & 2.7500 \\
\hline $\begin{array}{l}\text { Spermatogonia } \\
\text { cell counts }\end{array}$ & $186.1000^{c}$ & $196.5000^{b}$ & $07.4000^{\mathrm{a}}$ & $206.1000^{\mathrm{a}}$ & 2.9600 \\
\hline
\end{tabular}




\section{Discussion}

According to the results of this experiment, dietary L-Arg had a positive effect on all reproductive traits in male broiler breeder. These results are in accordance with the findings of Silva et al.[12] who reported that L-Arginine supplementation had a positive effect on egg production and hatchability in breeders. In this regard, it is well documented that dietary L-Arg might be potentially used to improve the fertility of broiler breeder hens due to the sperm penetration in the perevitelline membrane[13]. It has been reported that cells endogenously synthesize NO via L-Arg oxidation by a family of NOS isoforms. Hellstrom et al.[14] showed that NO substance had a regulatory effect on the sperm motility and viability and consequently sperm fertilizing potential. It is cleared that, as in other systems, NO exerts a bimodal action on sperm motility; specifically, low concentrations of NO improve sperm motility, while high concentrations of NO reduce the motility of spermatozoa[15]. In regards to semen or sperm volume, it is indicated that L-Arg aspartate significantly increased sperm volume, concentration and motility through the antioxidative impact[16]. It has been confirmed that L-Arg enhances the rate of glycolysis, resulting in higher rates of adenosine triphosphate and lactate generation in spermatozoa[7]. However, important progress in L-Arg research suggests that this amino acid and its metabolites play a more complex role in the regulation of sperm characteristics.

The improvement in testes weight and relative testes weight in L-Arg treatment groups showed in this study might be related to the increase in testosterone concentration in serum as a result of L-Arg supplementation. It is well-known that testosterone has an important effect in spermatogenesis process and to maintain the spermatogenesis in testis[6]. Al Daraji et al.[17] observed that testosterone hormone is required to complete meiosis and spermatids differentiations in male broiler breeder. Arginine stimulates the secretion of pancreatic hormones and anterior pituitary hormones, thereby regulating the metabolism of protein, amino acids, glucose and fatty acids[8]. All these mechanisms help the host to adjust itself to an optimal status of reproduction. However, the exact mechanism of arginine in the metabolism pathway involved in male broiler breeder reproduction needs further research.

According to the results of the present study, it is concluded that dietary L-Arg had a positive effect on reproductive traits including semen quality and testes histology of roosters.

\section{Conflict of interest statement}

The authors hereby certify that they have no conflict of interest.

\section{References}

[1] Akhlaghi A, Ahangari YJ, Navidshad B, Pirsaraei ZA, Zhandi M, Deldar H, et al. Improvements in semen quality, sperm fatty acids, and reproductive performance in aged Cobb 500 breeder roosters fed diets containing dried ginger rhizomes (Zingiber officinale). Poult Sci 2014; 93(5): 1236-1244.

[2] Daryabari H, Akhlaghi A, Zamiri MJ, Pirsaraei ZA, Mianji GR, Deldar $\mathrm{H}$, et al. Oral administration of supplementary biotin differentially influences the fertility rate and oviductal expression of avidin and avidinrelated protein-2 in low- and high-fertility broiler line hens. Poult Sci 2015; 94(2): 289-295.

[3] Neuman SL, Lin TL, Heste PY. The effect of dietary carnitine on semen traits of white Leghorn roosters. Poult Sci 2002; 81(4): 495-503.

[4] Khan RU, Rahman Z-u, Javed I, Muhammad F. Effect of vitamins, probiotics and protein on semen traits in post-molt male broiler breeders. Anim Rep Sci 2012; 135(1-4): 85-90.

[5] Wu G, Bazer F, Davis T, Kim S, Li P, Marc Rhoads J, et al. Arginine metabolism and nutrition in growth, health and disease. Amino Acids 2009; 37(1): 153-168.

[6] Funahashi H. Induction of capacitation and the acrosome reaction of boar spermatozoa by L-arginine and nitric oxide synthesis associated with the anion transport system. Reproduction 2002; 124(6): 857-864.

[7] Hassanpour H, Teshfam M, Karimi Goodarzi A, Tajik P, Mirshokrae $\mathrm{P}$. In vitro effects of 1-arginine on motion parameters in ram epididyma sperm. Comp Clin Pathol 2010; 19(4): 351-355.

[8] Ren B, Cheng X, Wu D, Xu S-Y, Che L-Q, Fang Z-F, et al. Effect of different amino acid patterns on semen quality of boars fed with lowprotein diets. Anim Rep Sci 2015; 161: 96-103.

[9] Oyeyipo IP, Raji Y, Bolarinwa AF. Nitric oxide synthase inhibition ameliorates nicotine-induced sperm function decline in male rats. Asian Pac J Reprod 2015; 4(3): 212-216.

[10]NRC. Nutrient requirements of poultry. Washington. D.C.: National Academy Press; 1994.

[11]SAS. SAS Statistics User's Guide. Statistical Analytical System. 5th ed Cary, NC: SAS Institute Inc; 1999.

[12]Silva LMGS, Murakami AE, Fernandez JIM, Dalla Rossa D, Urgnan F. Effects of dietary arginine supplementation on broiler breeder egg production and hatchability. Braz J Poultry Sci 2012; 14(4): 233-304.

[13]Sharideh H, Esmaeile Neia L, Zaghari M, Zhandi M, Akhlaghi A, Lotfi L. Effect of feeding guanidinoacetic acid and L-arginine on the fertility rate and sperm penetration in the perivitelline layer of aged broiler breeder hens. J Anim Physiol Anim Nutr 2015; 100(2): 316-322.

[14]Hellstrom WJG, Bell M, Wang R, Sikka SC. Effect of sodium nitroprusside on sperm motility, viability and lipid peroxidation. Fertil Steril 1994 61(6): 1117-1122.

[15]Doshi SB, Khullar K, Sharma RK, Agrawal A. Role of reactive nitrogen species in male infertility. Reprod Biol Endocrinol 2012; 10: 109-130.

[16]Stanislavov R, Nikolova V, Rohdewald P. Improvement of seminal parameters with Prelox: A randomized, double-blind, placebo-controlled cross-over trial. Phototherapy Res 2009; 23(3): 297-302.

[17]Al-Daraji HJ, Amen MH. Effect of the supplementation of the broiler breeder males ration with zinc on histological traits of testes. Int $J$ Appl Poultry Res 2012; 1(1): 10-14. 